\title{
PENERAPAN KOMPETENSI KONSELOR DALAM MEMBANTU KORBAN PELECEHAN SEKSUAL DENGAN KONSELING TRAUMATIK
}

\author{
Nurul Albertin', Dede Rahmat Hidayat ${ }^{2}$ \\ Email: nurulalbertin_bk18s2@mahasiswa.unj.ac.id ${ }^{1}$,dederhidayat@unj.ac.id ${ }^{2}$ \\ Universitas Negeri Jakarta ${ }^{1,2}$
}

\begin{abstract}
Abstrak
Konselor merupakan sebuah perjalanan seumur hidup yang tidak ada habisnya. Konselor merupakan seseorang yang sudah memiliki pendidikan profesi, memahami setiap kompetensi konselor dan menerapkan terhadap setiap klien. Kompetensi konselor dibagi menjadi empat yaitu pedagogik, professional, kompetensi sosial dan kompetensi pribadi. Konselor harus mampu menerapkan ini didalam pribadinya. Selain kompetensi ada juga karakteristik konselor antara lain kepercayaan publik (public trust), kode etik, kualifikasi, standart kompetensi dan kurikulum. Banyak permasalahan yang akan dihadapi oleh konselor karena setiap klien yang datang berbeda-beda mulai dari permasalahan yang ringan sampai yang rumit. Dari sekian banyak permasalahan yang dihadapi klien salah satu permasalahannya adalah pelecehan seksual. Pelecehan seksual dapat terjadi dimana saja dan dialami oleh siapa saja. Pelecahan seksual adalah tindakan asusila yang di lakukan pelaku dengan sengaja terhadap orang lain sehingga menimbulkan perasaan trauma pada diri seseorang. Salah satu terapi yang digunakan oleh konselor adalah konseling traumatik, proses konseling tersebut dapat dilakukan dengan beberapa kali pertemuan yaitu melihat trauma dan permasalahan yang dihadapi klien. Pada umumnya membantu klien yang mengalami pelecehan seksual dibutuhkan lebih dari sekali pertemuan karena konselor bertugas membantu klien menghilangkan trauma tersebut dan membuat klien menerima diri sendiri serta memaafkan dan menerima masalalunya. Tujuan dari penelitian ini adalah untuk mengetahui dan melihat penerapan kompetensi konselor dalam membantu korban pelecehan seksual. Konselor harus mampu menerapkan kompetensi professional konselor sehingga klien merasa nyaman, percaya dan aman serta mampu terbuka mengenai setiap persoalannya.
\end{abstract}

Kata Kunci: Kompetensi Konselor, Pelecehan Seksual, Konseling Traumatik

\begin{abstract}
Being a counselor is an endless journey of a lifetime. A counselor is someone who already has a professional education, understands each counselor's competencies and applies it to every client. Counselor competencies are divided into four namely professional pedagogic, social competence and personal competence. Counselors must be able to apply this in their personality. In addition to competence there are also characteristics of counselors including public trust, the Code of Ethics, Qualifications and standards of competence and curriculum. Many problems will be faced by the counselor because every client who comes in varies from mild to complex problems. One problem is sexual harassment. It can occur anywhere and is experienced by anyone. Sexual harassment is an act of immorality committed by the perpetrators intentionally towards others, causing a feeling of trauma to a person. The purpose of this research is to find out and see the application of counselor competencies in helping victims of abuse. Counselors must be able to apply the professional competency of the counselor so that the client feels comfortable, trustworthy and secure and is able to be open about every issue.
\end{abstract}

Keywords: Counselor Competencies; Sex Abuse; Traumatic Counseling

\section{PENDAHULUAN}

Konselor merupakan seseorang yang mampu membantu permasalahan klien dengan kemampuan yang dimilikinya. Semakin berkembangnya zaman konselor semakin dibutuhkan baik di keluarga, pendidikan, tempat kerja maupun rumah sakit karena permasalahan seseorang yang terjadi semakin kompleks. Dalam perihal ini ranah kerja konselor terbagi menjadi dua yaitu di sekolah yang sering disebut sebagai guru bimbingan konseling dan 
konselor yang sudah mengambil profesi, permasalahan dan jobdesk mereka tentu berbeda. Persoalan di sekolah yang biasa ditangani oleh guru bimbingan sekolah atau konselor sekolah seperti mengenai peserta didik yang bolos, peserta didik yang nilainya turun, orangtua dengan anaknya serta terkadang dapat membantu permasalahan antar teman sejawat. Dalam hal ini berbeda dengan konselor yang sudah mengambil profesi, dia akan membuka tempat praktik sendiri, menjadi dosen atau konselor di beberapa perusahaan dengan berbagai persoalan klien. Menjadi konselor adalah proses seumur hidup, selain menjadi konselor melalui proses yang terus berlangsung melampaui pendidikan formal dan termasuk mengikuti kegiatan-kegiatan yang terkait dengan bidang konseling dan kegiatan organisasi profesi.

Penelitian kali ini penulis memfokuskan mengenai penerapan kompetensi konselor dalam membantu korban pelecehan seksual dengan konseling traumatik. Klien yang datang sebagian besar adalah mahasiswamahasiwi yang bertahan dan mencoba baik-baik saja dengan semua kejadiankejadian buruk yang dialami, salah satunya merupakan pelecehan seksual yang mencangkup kekerasan seksual dan terjadi dimasa lampau. Peran konselor disini sangat dibutuhkan untuk membantu klien menghilangkan rasa trauma, memaafkan masalalu dan menerima diri sendiri atas kejadian yang pernah dialaminya. Dari sekian banyak terapi yang sering digunakan dalam menangani perihal pelecehan seksual adalah konseling traumatik. Dalam pemberian terapi tidak dapat dilakukan oleh sembarang orang. Harus seseorang yang ahli dalam bidangnya salah satunya adalah konselor.

\section{KAJIAN TEORI}

Konseling merupakan sebuah pekerjaan yang membutuhkan disiplin keilmuan atau profesi yang dilakukan oleh konselor. Konseling sebagai profesi yang bersifat membantu memiliki landasan ilmu dan teknologi serta wilayah praktik yang jelas dan dapat dibedakan dengan profesi-profesi lain yang bersifat membantu. Salah satu yang melakukan konseling adalah seorang konselor. Gibson dan Mitchell (2011) menyatakan bahwa para konselor professional harus terlatih sepenuhnya dan berkualifikasi agar sanggup memenuhi kebutuhan populasi konseli yang mereka tangani atau yang dipercaya kepada mereka.

Menurut (Sri, Caraka, Dody, 2016) Konselor merupakan profesi yang diperuntukan bagi setiap individu yang sedang berkembang dalam upaya 
pencegahan, pengembangan, eksplorasi, pemberdayaan, perubahan, kemandirian dan remediasi dalam kehidupan di dunia yang semakin kompleks dan penuh tantangan. Winkel, (2005) mengatakan konselor adalah seorang tenaga professional yang memperoleh pendidikan khusus di perguruan tinggi dan mencurahkan seluruh wilayah pada pelayanan bimbingan dan konseling. Prayitno \& Anti (2004) menuliskan bahwa konselor ialah tenaga inti dalam bidang pelayanan bimbingan dan konseling.

Dalam (Permendikbud) Nomor 111 tahun 2014 mengenai bimbingan dan konseling, konselor adalah guru bimbingan dan konseling di satu pendidikan yang bertugas merencanakan, melaksanakan, mengevaluasi, dan melakukan tindak lanjut layanan bimbingan dan konseling.

Menjadi konselor merupakan sebuah pelayanan dimana ia harus bekerja dengan, pikiran, waktu, hati, tubuh, perasaan secara bersamaan. Menjadi konselor adalah sebuah proses seumur hidup Gladding, (2011). Suatu profesi akan tertulis dalam undang-undang untuk melindungi dan mengesahkan secara tertulis hitam diatas putih seperti menurut UU Nomer 20 tahun 2003 mengenai sistem pendidikan nasional pasal 1 ayat 6 menyatakan bahwa pendidik merupakan tenaga kependidikan yang memiliki kualifikasi sebagai guru, dosen, konselor, pamong belajar, widyaiswara, tutor, instrukstur, fasilitator dan lainnya yang memiliki sebutan sesuai dengan kekhususan serta berpartisipasi dalam menyelenggarakan pendidikan di Indonesia.

\section{Menurut Sri Hartini konselor} memiliki syarat atau karakteristik sebagai suatu profesi. Karakteristiknya antara lain adalah (1) kepercayaan publik (public trust), kepercayaan publik akan menentukan definisi dari profesi konselor itu sendiri dan memungkinkan konselor untuk berfungsi dalam cara-cara yang professional; (2) kode Etik, dalam hal ini kode etik adalah pedoman sikap,tingkah laku dan perbuatan dalam melaksanakan tugas dan kehidupan sehari-hari. Kode etik profesi adalah norma yang harus diindahkan setiap anggota dalam melakukan atau melaksanakan tugas profesinya dalam kehidupannya di masyarakat; (3) Kualifikasi dan standart kompetensi; (4) kurikulum pendidikan profesi.

\section{Kualifikasi Konselor}

Seorang konselor tidak hanya menjadi pendengar untuk permasalahan klien yang dihadapi tetapi memiliki standart, kualifikasi dan kompetensi tersendiri yang harus dimiliki oleh 
konselor. Menurut Peraturan Menteri Pendidikan Nasional (Permendiknas) No 27 tahun 2008 mengenai kualifikasi akademik konselor, terdapat tujuh indikator yang harus dikuasi konselor, meliputi (1) Menguasai konsep dan praksis asesmen untuk memahami kondisi, kebutuhan dan masalah konseli; (2) Menguasai kerangka teoritik dan praksis bimbingan dan konseling; (3) Merancang program bimbingan dan konseling; (4) Mengimplementasikan program bimbingan dan konseling yang komprehensif; (5) Menilai proses dan hasil kegiatan bimbingan dan konseling; (6) memiliki kesadaran dan komitmen terhadap etika professional; (7) Menguasai konsep dan praksis penelitian dalam bimbingan dan konseling.

\section{Kompetensi Konselor}

Dalam peraturan Menteri Pendidikan Nasional nomor 27 tahun 2008, tentang standar kualifikasi akademik dan kompetensi konselor (SKAKK) dijelaskan bahwa sosok utuh kompetensi konselor mencakup kompetensi akademik, kompetensi profesional, kompetensi pribadi dan kompetensi sosial.

Kartadinata (2010:189) merujuk pada penguasaan konsep, penghayatan dan perwujudan nilai, penampilan yang bersifat membantu dan unjuk kerja professional yang akuntabel. Telah dijelaskan dalam PP 19/2005. Maka kompetensi akademik dan profesional konselor dapat dirumuskan ke dalam kompetensi pedagogik, kepribadian, sosial dan profesional.

1. Kompetensi pedagogik
a. Menguasai teori dan praktik pendidikan

b. Mengaplikasikan perkembangan fisiologis dan psikologis serta perilaku konseli

c. Menguasai esensi pelayanan bimbingan dan konseling dalam jalur, jenis dan jenjang satuan pendidikan.

2. Kompetensi kepribadian

a. Beriman dan bertaqwa kepada Tuhan Yang Maha Esa

b. Menghargai dan menjunjung tinggi nilai-nilai kemanusiaan, individualitas, dan kebebasan memilih

c. Menunjukkan integritas dan stabilitas kepribadian yang kuat

d. Menampilkan kinerja berkualitas tinggi

3. Kompetensi sosial
a. Mengimplementasikan kolaborasi interen di tempat kerja
b. Berperan dalam organisasi dan
kegiatan profesi bimbingan dan konseling 
c. Mengimplementasikan kolaborasi antar profesi.

4. Kompetensi profesional

a. Menguasai konsep dan praksis asesmen untuk memahami kondisi kebutuhan dan masalah konseli

b. Menguasai kerangka teoritik dan praksis bimbingan dan konseling

c. Merancang program bimbingan dan konseling

d. Mengimplementasikan program bimbingan dan konseling yang komprehensif

e. Menilai proses dan hasil kegiatan bimbingan dan konseling

f. Memiliki kesadaran dan komitmen terhadap etika professional

g. Menguasai konsep dan praksis penelitian dalam bimbingan dan konseling.

\section{Pelecehan Seksual}

Pelecehan seksual sering terjadi di sekitar kita tinggal, baik dilingkungan rumah, sekolah, tempat umum dan tempat bermain. Pelecehan seksual dapat dialami oleh siapa saja anak-anak, remaja bahkan orang dewasa sekalipun selain itu dapat terjadi pada laki-laki dan perempuan. Perihal seksual di Indonesia merupakan hal yang tabu atau hal yang tidak perlu di bicarakan dan ketika salah satu anggota keluarga, teman atau orang yang dikenal dan dirinya sekalipun mengalami pelecehan seksual kebanyakan akan diam dan tidak ingin membicarakan terhadap orang tua atau pihak yang berwajib karena merasa dirinya malu atau hal yang memalukan, tidak enak, takut dipandang sebelah mata atau merupakan aib untuk individu dan keluarga.

Tanpa disadari hal yang tidak membuat dirinya nyaman (seperti pelecehan seksual yang dialami) di simpan rapat-rapat dan dapat mempengaruhi psikologis seseorang untuk menilai akan dirinya sendiri, orang lain dan lingkungannya, selain itu akan mempengaruhi kehidupan sosial dan emosi individu tersebut.

Komisi Nasional Perlindungan Anak (KOMNAS PA) melaporkan tindak kekerasan anak yang terjadi pada tahun 2014 mulai januari-april 2014, terdapat 342 kasus dan paling banyak terjadi adalah di lingkungan sekolah. Data dari BPPM/FKP2PA provinsi Daerah Istimewa Yogyakarta menjelaskan bahwa pada tahun 2009, jenis kekerasan yang sering terjadi dan paling banyak dilakukan adalah kekerasan seksual, yakni mencapai 152 kasus $(72,7 \%)$ dan pada tahun 2010 pelecehan seksual berupa kekerasan seksual masih besar, yakni 113 kasus $(61,4 \%)$. Selain di Indonesia terdapat pula di Amerika utara terdapat sekitar 15-25\% wanita dan $5-1 \%$ pria yang mengalami 
pelecehan seksual saat mereka anak-anak dan sebagian besar pelaku adalah orang yang dikenal korban, sekitar 30\% adalah keluarga dari korban, paling sering adalah saudara laki-laki, ayah, paman atau sepupu dan itu mencapai sekitar $60 \%$ dan diluar keluarga mencapai sekitar 10\% (Finkelhor,1994).

Pelecehan seksual tidak hanya ada di ibu kota Jakarta data yang diambil oleh Syaiful bahri dan Fajriani (2015) terjadi pelecehan seksual di Aceh dengan delapan kabupaten dengan data yang diambil dari tahun 2012-2014 terdapat 224 kasus pelecehan yang terjadi dengan usia korban kurang dari 15 dan 15-30 tahun. Pelecehan seksual yang terjadi antara lain kekerasan seksual, pencabulan dan pemerkosaan presentase pelecehan seksual di Aceh dilakukan oleh tetangga (36\%), kenalan (29\%), tidak dikenal $(21 \%)$, pacar $(7 \% 0$, teman $(7 \%)$, keluarga (12\%) dan guru (9\%).

Selain terjadi pada anak pelecehan seksual yang berupa kekerasan seksual dapat terjadi juga kepada remaja salah satunya adalah kekerasan seksual dalam berpacaran hal ini diperkuat oleh data statistik yang mengindikasikan bahwa remaja memiliki resiko yang lebih besar untuk terlibat dalam kekerasan dalam hubungan pacaran dibandingkan dengan orang dewasa Straus dalam Nurislami \&
Hargono (2014). Kekerasan seksual remaja awal, akan lebih sering menjadi korban kekerasan dibandingkan dengan remaja akhir. Kekerasan merupakan segala bentuk tindakan yang mempunyai unsur pemaksaan, tekanan, perusakan dan pelecehan fisik maupun psikologis Baron dan Byrne, (2005).

Tindak kekerasan terdapat beberapa jenis yaitu secara fisik, psikis, serta seksual. Setiap kekerasan dapat menimbulkan efek jangka pendek maupun jangka panjang. Kekerasan dapat terjadi pada siapa saja, tidak hanya terjadi pada perempuan saja atau hanya pada lelaki saja. Kekerasan dapat terjadi pada berbagai tingkatan usia, seperti pembagian perkembangan remaja awal, tengah maupun remaja akhir. Kekerasan pun tidak mengenal strata sosial dan status hubungan misalnya dalam pernikahan ataupun dalam masa pacaran. Kekerasan dapat terjadi ketika seseorang menjalani proses pacaran (dating violence) namun kekerasan dalam pacaran ini seringkali tidak terekspos dan biasanya disembunyikan oleh korbannya. Bahkan seringkali tidak disadari oleh korban yang telah mengalami kekerasan dalam pacaran.

Kekerasan seksual (sexual abuse) merupakan jenis penganiayaan yang biasa dibagikan berdasarkan kategori pelaku 
Tower, (2002) 1. Familial abuse kekerasan seksual yang dilakukan oleh seseorang yang masih memiliki hubungan darah atau keluarga inti atau seseorang yang menjadi pengganti keluarga. 2 . Extrafamilial Abuse kekerasan yang dilakukan oleh orang lain (diluar keluarga korban) dan ini semua hanya $40 \%$ yang melaporkan peristiwa hal ini.

\section{Konseling Traumatik}

Prawirohardjo (2010) melihat trauma sebagai pengalaman yang mengejutkan, tidak terencana sehingga meninggalkan bekas luka serta kesan tersendiri yang mendalam pada jiwa dan psikis individu yang mengalaminya. Pickett dalam (Rahmat \& Alawiyah, 2020) menuliskan terdapat dua simtom yang dialami oleh individu yaitu (a) adanya ingatan yang terjadi secara terus menerus mengenai kejadian atau peristiwa yang dialaminya tersebut dan (b) mengalami mati rasa atau berkurangnya respon individu terhadap lingkungan, kondisi ini selanjutnya akan mempengaruhi fungsi adaptif individu dengan lingkungan, hal inilah yang menimbulkan trauma tersendiri.

Konselor menggunakan konseling traumatik dalam membantu klien yang mengalami pelecehan dan kekerasan seksual sehingga menimbulkan trauma tersendiri. Ketika seseorang sudah memiliki trauma tersendiri akan menimbulkan kepahitan, penyesalan, dendam, ketakutan, kecemasan, stess dan depresi. Individu akan cenderung memiliki citra yang buruk akan diri sendiri, sehingga mempengaruhi perkembangan, psikologis dan sosial. Etty Setiawan, (2016) menuliskan konseling traumatik diartikan sebagai bantuan yang bersifat terapeutis yaitu diarahkan untuk mengubah sikap, pola pikir dan perilaku konseli. Konseling ini dilakukan secara langsung yaitu tatap muka antara konselor dengan konseli dan melakukan wawancara.

Dalam proses wawancara tidak terstruktur dan formal, disini tugas konselor harus membuat konseli merasa aman, nyaman, percaya, dapat terbuka, jujur dan tidak memberikan judgment pada konseli, hal tersebut sangat dibutuhkan oleh konseli. Proses konseling traumatik harus memiliki arus yang jelas seperti fokus pada satu permasalahan yaitu gejala trauma yang dialami klien, aktifitas lebih banyak dilakukan oleh konselor yaitu dimana konselor berusaha untuk memberi arahan, mensugesti, meyakinkan bahwa dirinya berharga, mencari dukungan dari keluarga, teman klien, mengusulkan berbagai perubahan lingkungan untuk kesembuhan klien. Jika diperlukan klien dapat dialihtangankan 
atau referal kepada ahlinya dan yang terakhir adalah tujuan dimana konselor mengingatkan kembali konseli dimana proses konseling traumatik bertujuan pada pemulihan kembali klien pada keadaan sebelum trauma sehingga mampu menerima diri sendiri, memaafkan, menerima masalalu dan menyesuaikan diri dengan lingkungan sekitar.

Konseling traumatik memiliki tujuan yang harus dicapai ketika melakukan proses tersebut menurut Muro dan Kottman (Taty Fauzi,2012) menuliskan tujuan konseling traumatik adalah

a. Berpikir realistis, kejadian yang mengakibatkan trauma dan hal yang dialaminya adalah bagian dari kehidupan yang harus dilalui.

b. Mendapat pemahaman mengenai peristiwa dan situasi yang menimbulkan trauma.

b. Selain Muro dan Kottman tujuan konseling traumatik juga dituliskan oleh Rusman ( Etty Setiawan, 2016) dengan bertujuan menurunkan gejala kecemasan pasca trauma yaitu:

a. Menghilangkan bayangan traumatis

b. Meningkatkan kemampuan berpikir secara lebih rasional.

c. Membangkitkan minat terhadap realita kehidupan d. Memulihkan rasa percaya diri.

e. Memulihkan kelekatan dan keterkaitan dengan orang lain yang dapat memberi dukungan dan perhatian.

f. Kepedulian emosional serta mengembalikan makna dan tujuan.

\section{METODOLOGI PENELITIAN}

Penelitian ini menggunakan pendekatan kualitatif deskriptif dengan memberikan terapi yaitu konseling terapi. Menurut nasution (2003:5) bahwa "penelitian kualitatif pada hakikatnya ialah mengamati orang dalam lingkungan hidupnya, berinteraksi dengan mereka, berusaha memahami bahasa dan tafsiran mereka tentang dunia sekiarnya. Sugiyono (2009:15), pengertian penelitian kualitatif adalah penelitian yang berlandaskan pada filsafat post positivisme, digunakan untuk meneliti pada kondisi obyek yang alamiah, (sebagai lawannya eksperimen) dimana peneliti adalah sebagai instrumen kunci, pengambilan sampel sumber data dilakukan secara purposive dan snowball, teknik pengumpulan dengan tri-anggulasi (gabungan), analisis data bersifat induktif atau kualitatif, dan hasil penelitian kualitatif lebih menekankan makna dari pada generalisasi.

$$
\text { Sugiyono }
$$

mengemukakan bahwa penelitian kualitatif dilakukan ketika (1) Bila 
masalah penelitian belum jelas, masih remang-remang atau mungkin malah masih gelap; (2) Untuk memahami makna dibalik data yang tampak; (3) Untuk memahami interaksi sosial; (4) Untuk memahami perasaan orang; (5) Untuk mengembangkan teori; (6) Untuk memastikan kebenaran data; (7) Meneliti sejarah perkembangan.

Penelitian ini menggunakan metode wawancara, Esterberg (sugiyono, 2009: 72) memaparkan bahwa "a meeting of two persons to exchange information andidea through question and responses, resulting in communication and joint construction of meaning abaout a particular topic". Wawancara adalah merupakan pertemuan dua orang untuk bertukar informasi dan ide melalui tanya jawab, sehingga dapat dikonstruksikan makna dalam suatu topik tertentu. Danial (2009:71) menuliskan bahwa wawancara adalah teknik data dengan cara mengadakan dialog, tanya jawab antara penelitian dan responden secara sungguh-sungguh.

Subyek dalam penelitian ini adalah seorang konselor yang sudah menduduki profesi konselor selama 16 tahun yang dimulai dari 2003-2019. Beliau bernama Susi Fitri dan sekarang telah menjabat koordinator prodi di Universitas Negeri Jakarta. Alat yang digunakan untuk mengumpulkan data adalah wawancara.

\section{HASIL PENELITIAN}

Berdasarkan hasil wawancara yang telah dilakukan dengan konselor dengan beberapa kali pertemuan, dengan pengalaman yang cukup lama menjadi konselor tentunya mengalami dan belajar banyak hal dari lingkungan dan klien itu sendiri. Susi Fitri lahir pada 23 november 1972 dan mengenyam pendidikan di IKIP ketika strata 1, Universitas Indonesia untuk magister dengan jurusan psikologi SDM, Universitas Malang untuk S3 dan Universitas Padang untuk mengambil gelar profesi. Beliau tertarik untuk menjadi konselor karena pada dasarnya tertarik pada orientasi manusia. Menjadi dosen UNJ merupakan salah satu pekerjaannya dimana akan secara langsung berinteraksi dengan mahasiswa dan ini menjadi salah satu tujuannya sebagai seorang konselor yaitu setiap orang terutama mahasiswa dan kliennya memiliki mental yang lebih baik tidak terikat pada masa lalu.

Menurut beliau menjadi seorang konselor adalah sebuah perjalanan (secara akademik memang benar konselor) disebut sebagai perjalanan berarti suatu yang tidak pernah sampai karena saya akan terus memperbaiki diri saya setiap hari serta harus belajar dari klien baik itu dari konseli-ng yang gagal maupun berhasil, karena setiap klien berbeda 
karakter ada yang menurut klien saya adalah konselor yang baik tetapi ada juga yang tidak oleh karena itu saya harus belajar setiap harinya dan tidak semua konselor cocok untuk semua kalien.

Dari setiap aspek yang terkandung dalam konsep kompetensi seorang pendidik (knowledge, understanding, skill, value, attitude dan interst) yang menjadi tantangan tersendri adalah value adalah tantangan tersendiri baginya karena value itu berhubungan dengan norma-norma masyarakat sedangkan ada klien yang memang dia bermasalah karena tidak setuju dengan norma masyarakat yang ada atau memang norma tersebut yang tidak harusnya seperti itu, oleh karena itu saya harus memiliki seni dalam konseling. Seperti halnya Isu seksualitas, isu agama apakah harus mengikuti norma masyarakat atau norma individu sedangkan didalam konseling kita memiliki the best inters of over clien, sedangkan kepentingan terbaik klien adalah hal utama dan dalam value itu saya masih harus struggle sendiri untuk saya. Itulah yang beliau katakana ketika proses wawancara berlangsung.

Permasalahan yang ada dari berbagai klien terdapat kasus yang ada satu kasus yang mempengaruhinya yaitu mahasiswa pada tahun 2006 yang mengalami pelecehan seksual pada umur
5 tahun dan ibunya menutupi kasus itu karena malu dengan tetangga (karena pelakunya tetangga) dan hal itu mempengaruhi relasinya dengan ibunya sehingga beliaumelakukan konseling dengan suatu teknik dan ternyata dapat membongkar kemarahannya yang selama ini terpendam.

Penerimaan tanpa syarat merupakan bagian penting dari proses konseling sehingga mampu membantu konseli yang sebenarnya tidak menyadari bahwa yang dia alami lebih dari sekedar konflik. Hal itu mendorongnya memastikan untuk membahas isu-isu seksualitas karena di Indonesia isu tersebut adalah hal yang tabu dan banyak orang mengalami isu tersebut sehingga merasa depresi, tidak dihargai, tertekan tetapi malu mengungkapkan dan orang lain akan memiliki nilai perubahan akan dirinya sedangkan kasus tersebut harus diselesaikan karena akan mengganggu sekolahnya, hubungan sosialnya bahkan pribadinya sendiri tetapi di sini lebih mengutamakan mengenai nilai, prestasi, masuk sekolah terbaik atau tidak permasalahan itu bisa jadi berkaitan dengan permasalahan pribadinya seperti karena adanya pelecehan seksual.

Di sisi lain betapa manusia mempunyai kemampuan resiliansi yang sangat tinggi mempunyai kemampuan 
bertahan yang sangat tinggi karena dari kasus-kasus pelecahan seksual itu bisa terbongkar ketika klien berumur 23 atau 22 tahun bahkan lebih dari umur tersebut bebrarti klien cukup mampu bertahan dengan dia lulus setiap pendidikan, punya pacar, punya teman dan lain sebagainya dan dari situ meyakinkan saya bahwa manusia memiliki kekuatan yang lebih lama untuk bertahan dan melewati setiap hal yang ada selain itu menumbuhkan saya untuk menjadi pendidik yang mampu melahirkan konselor yang benar dan peduli sehingga mampu membantu klien mengurangi hal itu semua secara cepat. Dalam penyelesaian permasalahan klien beberapa kali menggunakan konseling traumaik karena sesuai dengan permasalahan yang klien hadapi.

\section{KESIMPULAN}

Berdasarkan hasil penelitian yang penulis lakukan dengan wawancara bersama salah seorang konselor yang sudah cukup lama mengenyam dunia konselor ini bahwa menjadi seorang konselor adalah merupakan sebuah perjalanan seumur hidup yang tak ada habisnya. Menjadi konselor dibutuhkan pendidikan secara formal yang harus di lalui. Dari semua pengertian konselor diatas penulis menari kesimpulan bahwa Konselor merupakan seseorang yang sudah memiliki pendidikan profesi, memahami setiap kompetensi konselor dan menerapkan terhadap setiap klien.

Kompetensi konselor dibagi menjadi empat yaitu pedagogik professional, kompetensi sosial dan kompetensi pribadi. Konselor harus mampu menerapkan ini didalam pribadinya. Selain kompetensi ada juga karakteristik konselor antara lain kepercayaan publik (public trust), kode etik, kualifikasi dan standart kompetensi dan kurikulum.

Pelecehan seksual adalah perbuatan yang tidak menyenangkan bagi siapa saja. Karena ini akan berdampak buruk untuk korban dan keluarga korban. Pelecahan seksual adalah tindakan asusila yang di lakukan pelaku dengan sengaja terhadap orang lain sehingga menimbulkan perasaan trauma pada diri seseorang. Pelecehan seksual terjadi dimana saja dan terjadi oleh siapa saja.

Konseling traumatik merupakan salah satu terapi yang dapat digunakan oleh konselor untuk menghadapi klien yang memiliki trauma tersendri dengan memfokuskan tujuan yaitu penyembuhan konseli. Trauma pada diri seseorang terbagi menjadi dua yaitu adanya ingatan yang terjadi secara terus menerus mengenai kejadian atau peristiwa yang dialaminya tersebut dan mengalami mati rasa atau berkurangnya respon individu terhadap lingkungan, kondisi ini 
selanjutnya akan mempengaruhi fungsi adaptif individu dengan lingkungan.

\section{DAFTAR PUSTAKA}

Edwards, J. R., Caplan, R. D., \& Harrison, R. V. (1998). Person-environment fit theory: conceptual foundations, empirical evidence, and direction for future research. In C. L. Cooper, Theories of organizational stress (pp. 28-67). Oxford: Oxford University Press.

Etty Setiawati. (2016). Konseling traumatik pendekatan CognitifBehavior Therapy.. Al-Tazkiah, 8196

Evans, K. M., \& Larrabee, M. J. (2002). Teaching the multicultural counseling competencies and revised career counseling competencies simultaneously. Journal of Multicultural Counseling and Development, 21-39.

Gall, D. M., Gall, P. J., \& Borg, R. W. (2003). Educational Research: An Introduction. Boston: Ablongman.

Gustafon, K. L., \& Branch, R. M. (2002). Survey of instructional Development models. New York: ERIC Clearinghouse on Information and Technology.

Gustafon, K. L., \& Branch, R. M. (2002). Survey of instructional Development models. New York: ERIC Clearinghouse on Information and Technology.

Hayatul Khairul Rahmat \& Desi Alawiyah. (2020). Konseling Traumatik: Sebuah Strategi Guna Memproduksi Dampak Psikologis Korban Bencana Alam. Jurnal Mimbar. 34-44

Lofquist, L. H., \& Dawis, V. R. (1991). Essentials of person-environmentcorrespondence Minneapolis: University Minnesota Press.
Marini, I., \& Stebnicki, M. A. (2009). The professional counselor's desk reference. New York: Springer.

Michael Page. (2015). 2015 Employee Intentions Report Indonesia. Jakarta: Michael Page.

Nurislami, N. R., \& Hargono, R. (2014, Desember).

KEKERASAN

DALAM PACARAN DAN GEJALA DEPRESI PADA REMAJA. Jurnal Promkes, II(2), 173-185.

Osborn, D. S., \& Baggerly, J. N. (2004). School counselors' perceptions of career counseling and career testing: preferences, priorities, and predictors. Journal of Career Development, 31(1), 45-59.

Peraturan Menteri Pendidikan nasional Nomer 27 tahun 2008 tentang standar kualifikasi akademik dan kompetensi konselor

Peraturan Pemerintah No 19 Tahun 2005 tentang Standar Nasional Pendidikan

Prawirohardjo,S. (2010). Ilmu Kebidanan. Jakarta:Yayasan Bina Pustaka

Randang, F. B. (2011). Kesiapan Tenaga Kerja Indonesia dalam Menghadapi Persaigan dengan Tenaga Kerja Asing. Servanda, 66-73.

Rogers, M., \& Creed, P. (2000). Schoolto-work transition: from theory to practice. Jpurnal of Career Development, 9(3), 1-21.

Syaiful Bahri \& Fajriani. (2015). Suatu Kajian Awal Terhadap Tingkat Tingkat Pelecehan Seksual di Aceh. Majelis Pendidikan daerah Aceh. Jurnal Pencerahan. 50-65

Taty Fauzi. (2012). Comprehensive Guidance and Counseling Services in Schools. Guidance and Counseling Departement Yogyakarta. 89- 92

Undang-undang Republik Indonesia Nomer 14 tahun 2005 tentang Guru dan Dosen 